\title{
IS MEASURING OF TEMPERATURE FLUCTUATIONS FOLLOWING BARK BEETLE INFESTATION IN DIFFERENTIALLY MANAGED FORESTS OBJECTIVE?
}

\author{
KAROLÍNA BÍLÁ* \\ Department of Biodiversity Research, Global Change Research Institute CAS, Bělidla 986/4a, 60300 Brno, Czech Republic \\ *Corresponding author: kcerna@volny.cz
}

\begin{abstract}
Proper management of woods infested by bark beetle - clearing infested trees to prevent spread of bark beetle, or leaving them to preserve biodiversity - is a hotly debated topic. Differences in temperature regime between differentially managed areas are often-used arguments in these discussions. Results from the field measurements are confusing. Therefore, here we review previous studies and report our results of using thermal sensors in the field to determine the factors that might affect the differences in temperature reported in previous papers. Our results indicate that the variability recorded in one particular habitat, dry forest, is associated with the specific characteristics of the locality of each microsite/sensor. We conclude that it is important to consider not only the temperatures recorded but also describe microsites in detail in terms of vegetation structure, sunshine or numbers of trees per unit area.
\end{abstract}

Keywords: bark beetle; climate change; forest management; iButton; temperature; thermal sensor

\section{Introduction}

Recent discussions about the effect the predicted changes in climate will have on the Šumava National Park (NP) reveal a difference in opinions on how best to manage forests attacked by bark beetles in order to preserve natural conditions and the biodiversity in this valuable area. The first opinion recommends clear felling infested forest in order to stop the bark beetles spreading further (Wermelinger 2004; Zahradník 2004), the second prefers no human interference with natural processes and leaving the dead trees standing (Jonášová and Prach 2004; Hais et al. 2009).

One of the main arguments is that the microclimate in forest differently managed after bark beetle attack differs. Clear felling of infested trees might reduce the number of bark beetles; however, it can also negatively affect the temperature and water regime at such sites (Kindlmann et al. 2012; Bílá 2016). What happens if dead trees are left standing at infested sites and no management is applied?

Several studies report differences in microclimate in cleared (Fig. 1) compared to dead (Fig. 2) and green forests (Tesař et al. 2004; Hais and Kučera 2008; Šantrǔčková et al. 2010; Kindlmann et al. 2012; Hojdová et al. 2015; Matějka et al. 2016) but the results are inconsistent. Some authors claim that the climate in a dead forest is more similar to that in a green healthy forest (Šantrůčková et al. 2010; Kindlmann et al. 2012; Matějka et al. 2016). Others claim that it is more similar to that in a clear felled area of forest (Hais and Pokorný 2004; Tesař et al. 2004; Hojdová et al. 2015). Which is closer to the truth? This review attempts to resolve such contrary statements and elucidate microclimate changes, particularly in temperature, in the Šumava NP.

\section{Methods}

Published papers dealing with temperature changes in the Šumava NP are based either on data loggers/thermal sensors or on a combination of remote sensing with GIS layers. These measurements usually compare microclimate conditions in green mature forest, dead dry forest and clearings in order to propose the best type of management to preserve natural forest habitats in the Šumava Mts.

\section{Remote sensing/GIS}

Studies based on data from remote sensing record significant warming in areas of forest attacked and killed by bark beetles. Hais and Kučera (2008) present changes in land cover and associated changes in temperature ranging from the coldest to the warmest associated with the decay of mountain spruce forests. They measured a mean temperature increase of $5.2^{\circ} \mathrm{C}$ in the clear-felled areas and of $3.5^{\circ} \mathrm{C}$ in spruce forest killed by bark beetles (examples of these habitats are presented in Figs. 1 and 2). However, forest areas of conservation interest are located at higher altitudes and this might be important in determining the difference when using remote sensing (Barry 1992).

\section{Data loggers/thermal sensors}

Measuring temperatures with thermal sensors is more accurate in terms of focusing on specific localities. Sensors are usually placed below the ground, on the surface, above the herbaceous layer or in the air (Fig. 3). The advantage of thermal sensors is that they record temperatures continuously in adjusted time sequences. Their placement determines the level of radiation from the sun they are exposed to (sensors can be placed underground or in vegetation or exposed to direct sunlight) and con- 


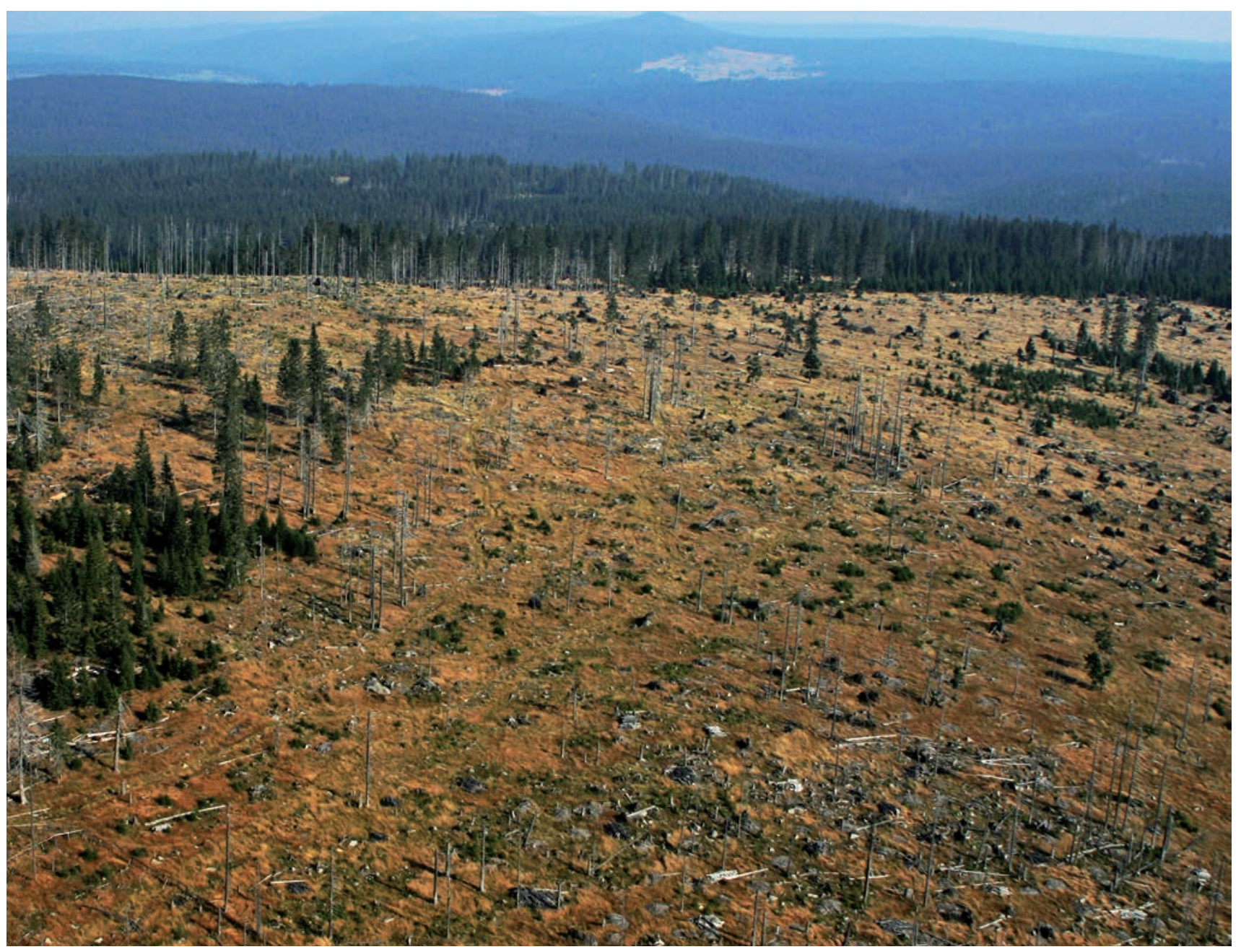

Fig. 1 Aerial photograph of a clear felled area of forest in the Šumava NP (author: Zdenka Křenová).

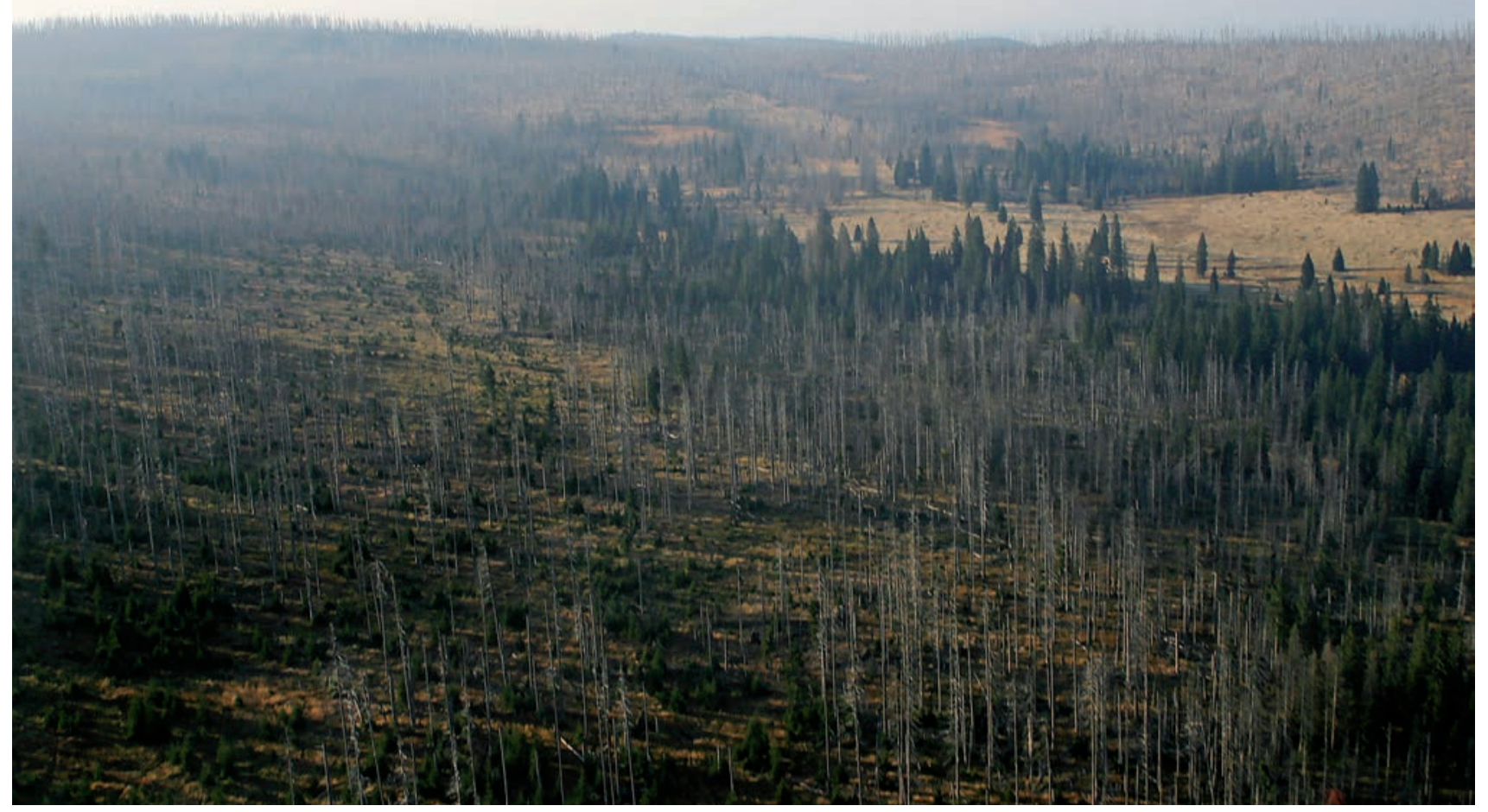

Fig. 2 Aerial photograph of a dead forest area that resulted from a bark beetle attack being naturally recolonized by young trees of Picea abies in the Šumava NP (author: Zdenka Křenová). 


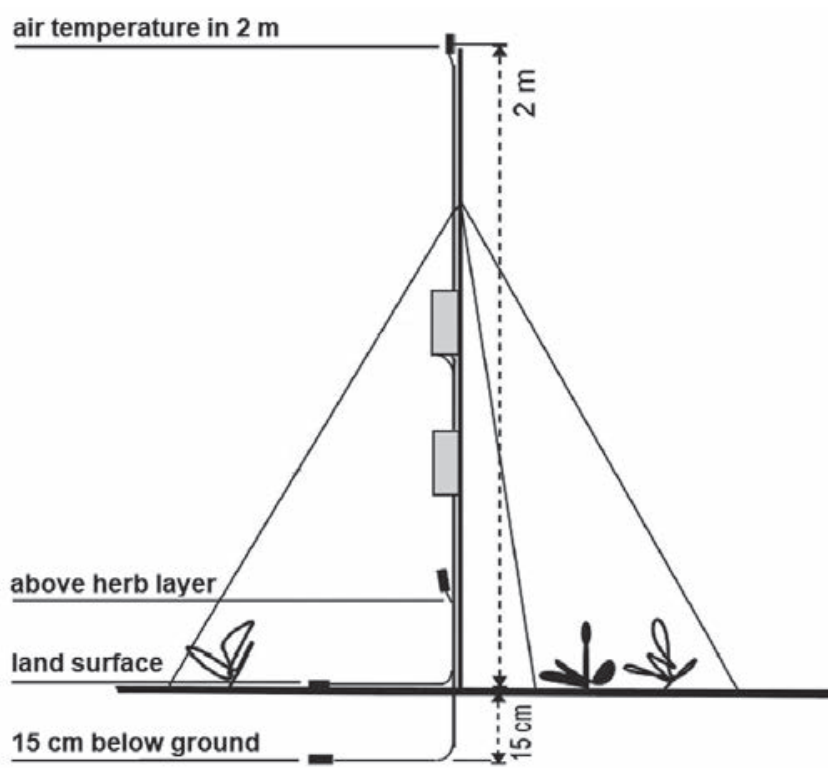

Fig. 3 Thermal sensors placed at different heights: $15 \mathrm{~cm}$ below the ground, on the surface, above the herbaceous plant layer and $2 \mathrm{~m}$ above the surface of the ground.

sequently the values recorded differ accordingly. We assume that differences in the degree of exposure of sensors to sunlight is one of the reasons why the published results differ.

Thermal sensors were used by several authors and one group recorded very similar temperature conditions in dead forest and green healthy forest, whereas other scientists recorded similar temperatures in dead forest and clearings. All authors agree on that temperature fluctuations are lowest in green living forest. Šantrůčková et al. (2010) report the peak day and night temperatures recorded during August in the vicinity of Březník in the Šmava NP. In dead and green forest, they fluctuated very similarly, between $5-10^{\circ} \mathrm{C}$ and in clearings the fluctuations were greater than $30^{\circ} \mathrm{C}$. Slightly higher temperatures were recorded in the dead forest (Kindlmann et al. 2012), namely the maximum air temperature recorded at a height of $2 \mathrm{~m}$ : in green forest it was $21.6^{\circ} \mathrm{C}$, in dry forest $34.6{ }^{\circ} \mathrm{C}$ and in clearing $39.7^{\circ} \mathrm{C}$. These results confirm those of Hais and Kučera (2008) that temperatures and daily amplitudes are greater in dead spruce forests than in green forests; however, temperatures in clearings are even higher than in dead spruce forests. Pokorný (2011) mentions an increase in the maximum temperatures in dry forest of almost about $20^{\circ} \mathrm{C}$, which is the same as in clearings.

Hojdová et al. (2005) present similar results with the maximum daily temperature amplitude above herbaceous plants in dead forest on average $14.5^{\circ} \mathrm{C}$ and in clearings $16.7^{\circ} \mathrm{C}$ during the vegetative season in 2002 and 2003. Moreover, Tesař et al. (2004) suggest the living and transpiring vegetation has a cooling effect and that the most extreme thermal environment is recorded in dead forest (daily maximum temperature measured: dead forest above $30^{\circ} \mathrm{C}, 23-25^{\circ} \mathrm{C}$ and living forest $22^{\circ} \mathrm{C}$ ).

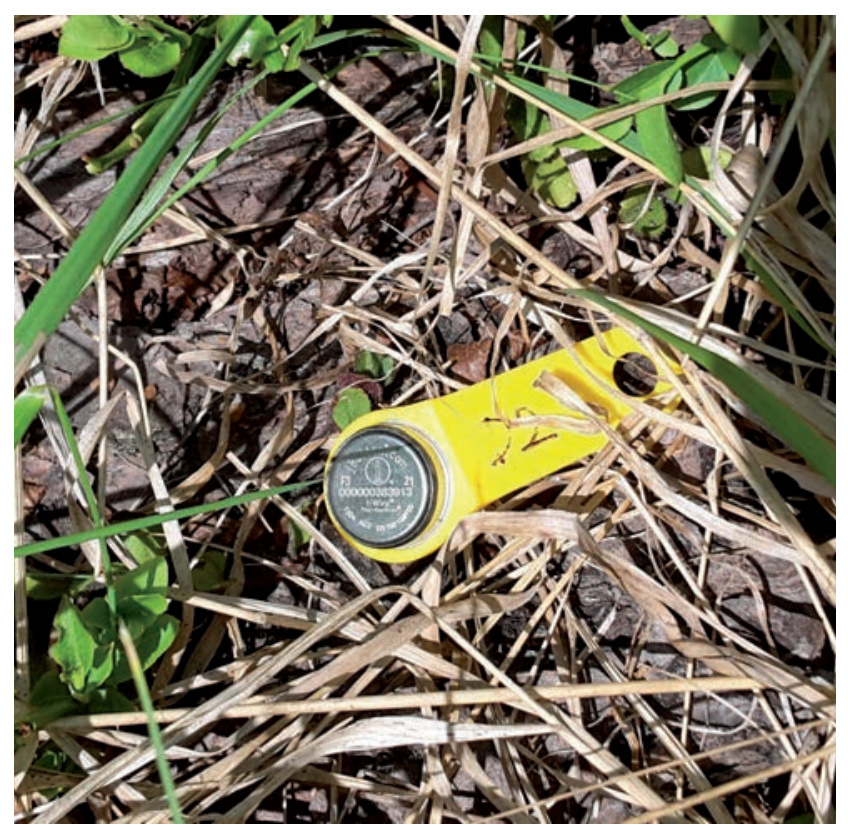

Fig. 4 Thermochron/iButton (model DS1921G) - a practical and inexpensive data logger of small size.

We conducted a small experiment with thermochrons/ iButtons (model DS1921G, Fig. 4) and exposed five thermochrons in dry forest killed by bark beetles $>10$ years previously. We attempted to select microsites with different types of vegetation cover and exposure to different levels of sunshine (Table 1). Temperatures were measured every hour.

The main goal of this small experiment was to reveal that there could be large differences in temperatures recorded even within one type of habitat (dry forest attacked and killed by bark beetles more than 10 years previously). Variability in the recordings of the 5 iButtons is presented in Figs. 5 and 6, in which temperature fluctuations (i.e. maximum - minimum daily temperatures) and maximum daily temperatures are displayed. There is an obvious effect of the structure of the vegetation, with shading important in reducing the exposure to direct sun light.

\section{Discussion}

Temperature regime in the Šumava NP has recently been widely discussed among politicians and scientists. There is evidence that increased temperatures promote bark beetles to attack larger areas of forest and cause devastating damage. Bečka and Beudert (2016) report a summer air temperature increase of about $2{ }^{\circ} \mathrm{C}$ since 1978. In particular, droughts and increases in temperature are favourable conditions for bark beetle attacks, which occur more frequently and are more serious under these conditions (Hais and Kučera 2008; Kindlmann et al. 2012). Bark beetles benefit from higher temperatures as they are able to raise two rather than one generation per year at high altitudes (Økland et al. 2015). Therefore, 


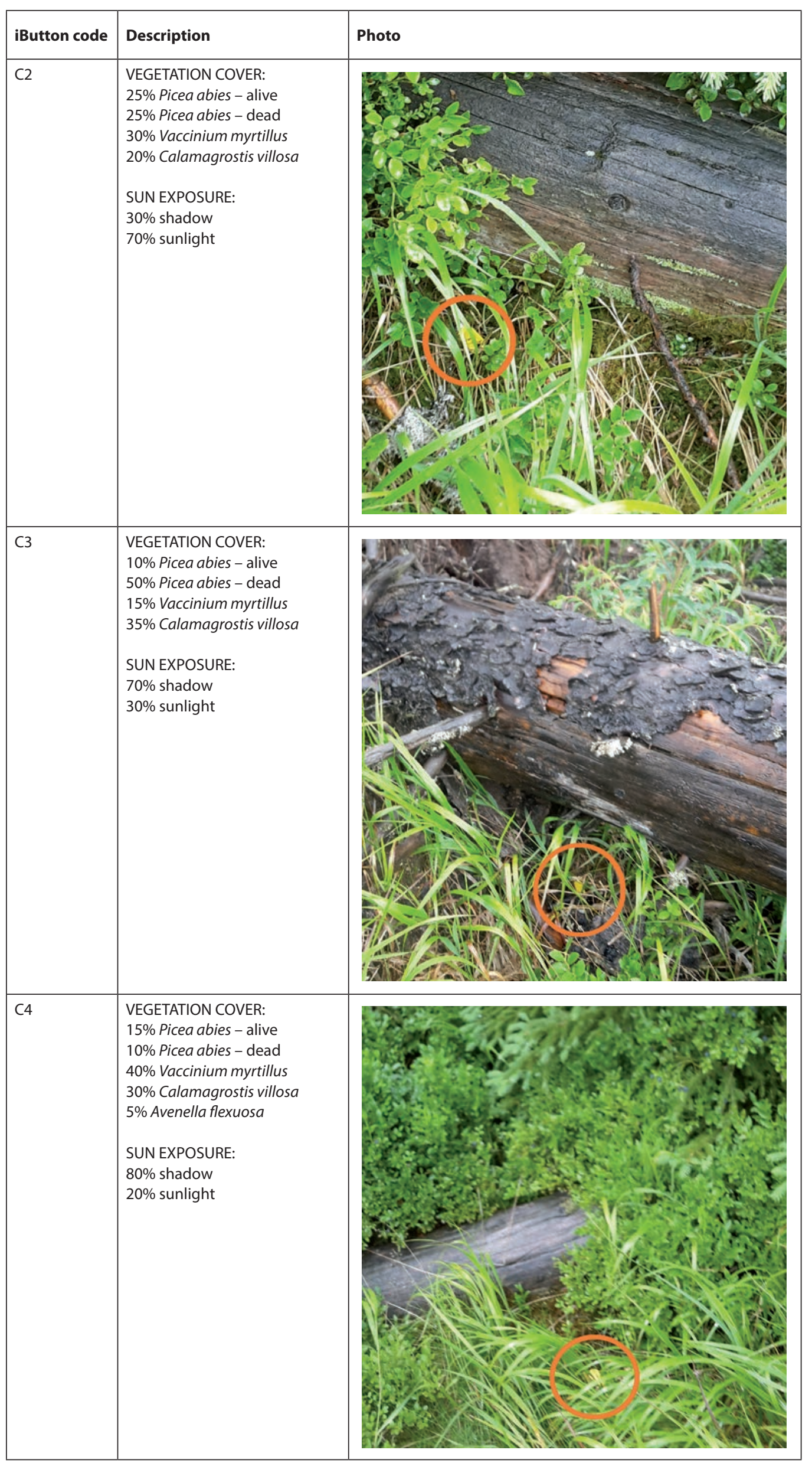




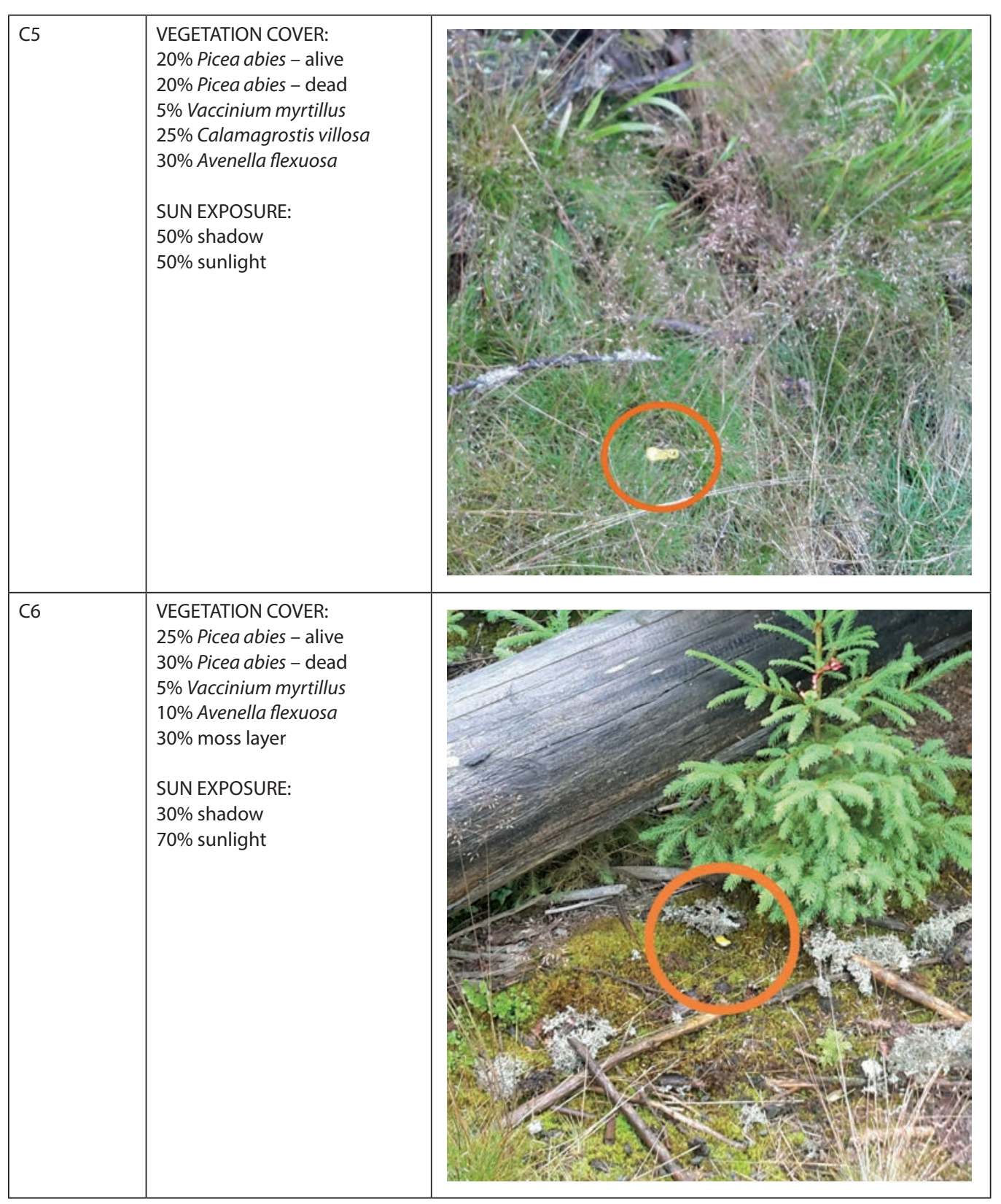

Table 1 Five microsites with different vegetation cover and exposure to sun in dry unmanaged forest. Red circles indicate position of the iButton.

there are long debates about the proper management of infested woods. One proposal is to fell and remove every infested tree, while others want to leave dead trees standing and in so doing help the regeneration of understory vegetation.

One of the arguments is that changes in microclimate occur in dry dead forest and clearings. Here, we compare several studies with very different results and we would like to elucidate why the measurements differ. After a short field-test with iButtons we suppose that one of the most important factors is the microclimate in which thermal sensor is placed. That is, vegetation cover and shadow/sunshine must be taken into account. In dry forest, the shading from standing dead stems and density of these stems is another factor that needs to be considered. Furthermore, forest regeneration was observed at sites after bark beetle attack, i.e. in standing dry forest.
Clearings can affect a site so that natural forest regrowth will not be possible. Cut trees and wood transport from the site changes the biotic and abiotic conditions at a site. The moss layer might disappear and competitive species of grass (Calamagrostis villosa, Avenella flexuosa) dominate the herbaceous plant layer (Kučerová et al. 2008). Several studies mention that large gaps in forests (more than $15 \mathrm{~m}$ in diameter) host much lower seedlings densities and present a more competitive environment for understory vegetation (Grenfell et al. 2011; Downey et al 2018). In contrast, smaller gaps in forests caused by disturbances provide space for new species and promote biodiversity. Forest gaps or their edges are often recognized as hotspots of insect diversity (Müller et al. 2007; Kautz 2013). Thus, native bark beetles play an important role in forest ecosystems around the world and commonly help promote forest succession (Bentz et al. 2010). 


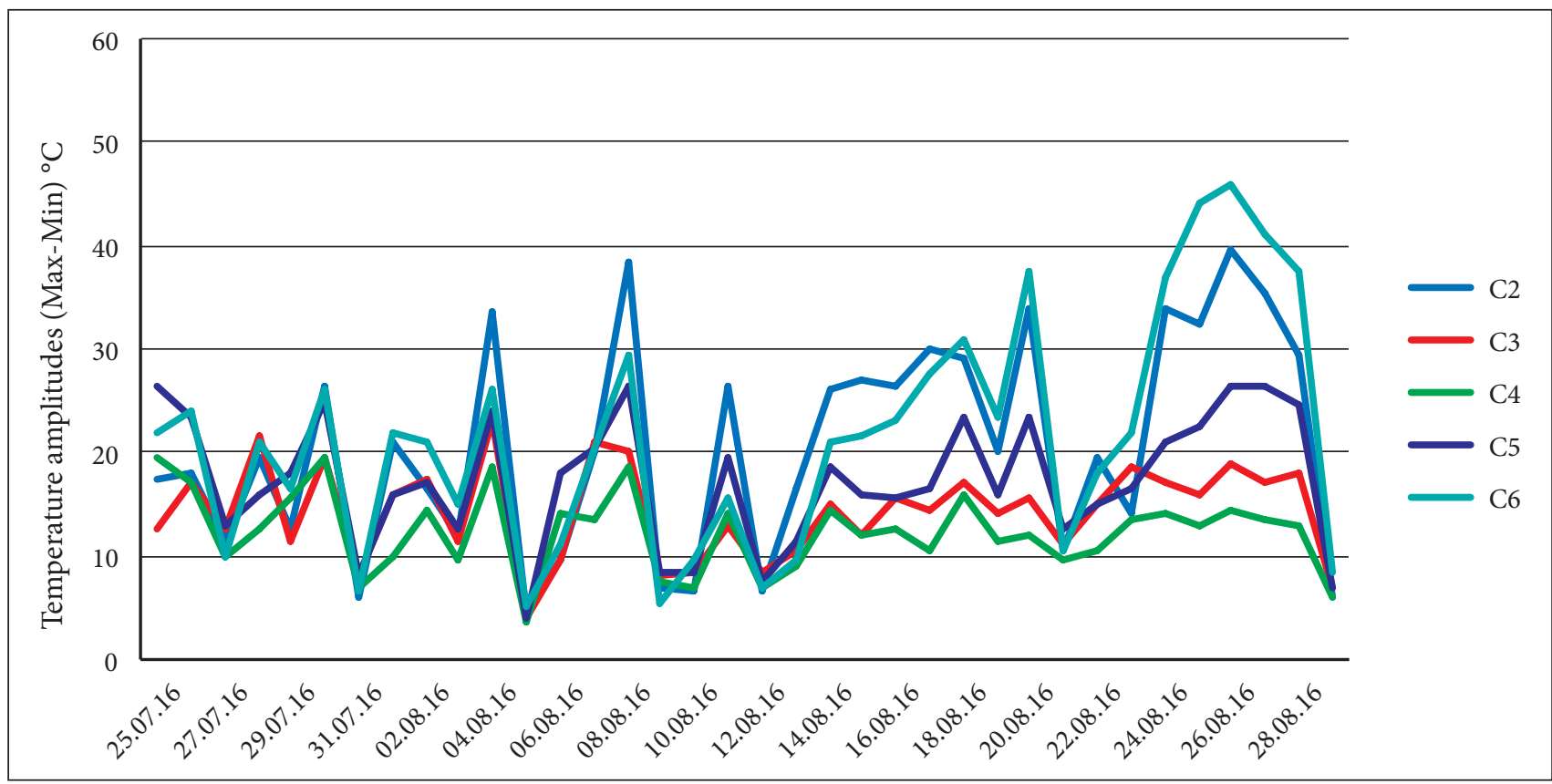

Fig. 5 Differences between the minimum and maximum daily temperatures recorded by iButtons (C2-C6) placed in a dead forest in July and August 2016.

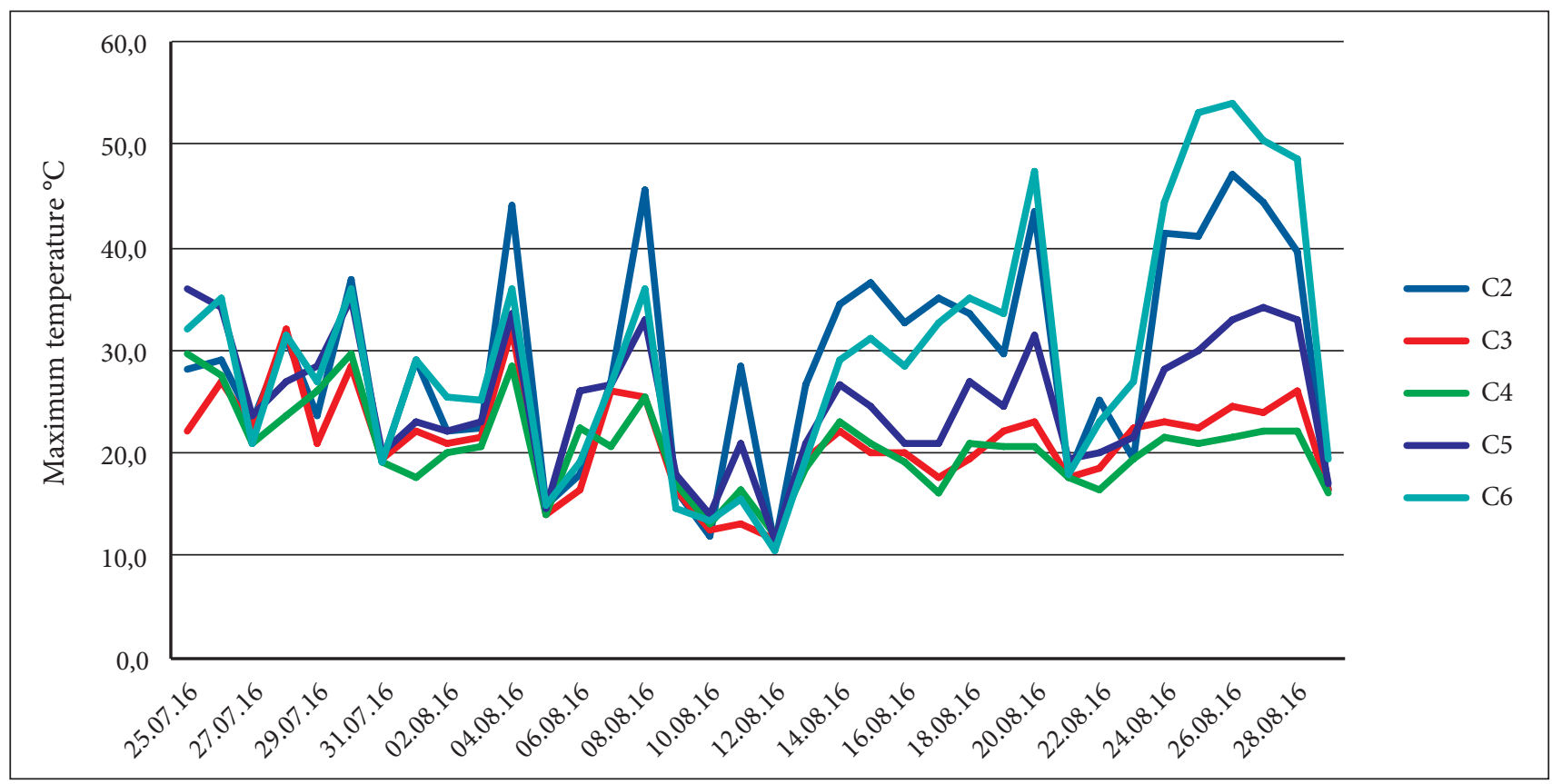

Fig. 6 Maximum daily temperatures recorded by iButtons (C2-C6) in a dead forest in July and August 2016.

In dead forest, herbaceous plants and mosses survived undamaged at our study sites. There is also a positive effect of the shading of undergrowth by dead trees even though these trees no longer transpire. Under dead trees, new forest regenerates fast and without any management or additional costs (Čížková et al. 2011). Cleared areas, on the other hand, are not very favourable for tree seedlings because of changed structure in the vegetation, an open canopy and exposure to direct sunshine, together with changes in the temperature and water regimes (Jonášová and Prach 2004; Schwarz 2013; Bílá 2016). Moreover, artificial planting is expensive and is subject to many risks. Trees are usually all planted at the same time, which results in a forest in which the trees are all the same age. Such a forest needs permanent care and is liable to natural disturbances and enemies.

Both types of management after a forest is attacked by bark beetle were applied in the Šumava National Park. Differences in forest succession and environmental conditions were recorded recently at these sites. Based on this knowledge, we should not forget that the main aim of national parks is to protect endangered habitats and their biodiversity (Šíp 2004; Nikolov et al. 2014; Kindlmann and Křenová 2016). Disturbances, dying trees, natural regeneration and spontaneous regrowth are common and natural components of national parks. 


\section{Acknowledgements}

This research was supported by the MSMT within the National Sustainability Program I (NPU I), grant number LO1415.

\section{REFERENCES}

Barry RG (1992) Mountain weather and climate, 2nd edn. Routledge, London, New York.

Bečka P, Beudert B (2016) Kůrovec a voda. Jak bezzásahovost ovlivňuje vodní režim na Šumavě. Šumava, jaro: 16-17. In Czech.

Bentz BJ, Régnière J, Fettig CJ, et al. (2010) Climate change and bark beetles of the western United States and Canada: direct and indirect effects. BioScience 60: 602-13.

Bílá K (2016) Are bark beetles responsible for drouhgts in the Šumava Mts.? Eur J Environ Sci 6: 108-113.

Čížková P, Svoboda M, Křenová Z (2011) Natural regeneration of acidophilous spruce mountain forests in non-intervention management areas of the Šumava National Park - the first results of the Biomonitoring project. Silva Gabreta 17: 19-35.

Downey M, Valkonen S, Heikkinen J (2018) Natural tree regeneration and vegetation dynamics across harvest gaps in Norway spruce dominated forests in southern Finland. Canadian J Forest Res 48: 524-534.

Grenfell R, Aakala T, Kuuluvainen T (2011) Microsite occupancy and the spatial structure of understorey regeneration in three late-successional Norway spruce forests in northern Europe. Silva Fenn 45: 1093-1110.

Hais M, Jonášová M, Langhammer J, Kučera T (2009) Comparison of two types of forest disturbance using multitemporal Landsat TM/ETM+ imagery and field vegetation data. Remote Sens Environ 113: 835-845.

Hais M, Kucera T (2008) Surface temperature change of spruce forest as a result of bark beetle attack: Remote sensing and GIS approach. Eur J Forest Res 127: 327-336.

Hais M, Pokorný J (2004): Changes in land cover temperature and humidity parameters resulting from spruce forests decay. Aktuality šumavského výzkumu II: 49-55.

Hojdová M, Hais M, Pokorný J (2005) Microclimate of a peat bog and of the forest in different states of damage in the National Park Šumava. Silva Gabreta 11: 13-24.

Jonášová M, Prach K (2004) Central-Europen mountain spruce forests: regeneration of tree species after a bark beetle outbreak. Ecol Eng 23: 15-27.
Kautz M, Schopf R, Ohser (2013) The "sun-effect": microclimatic alterations predispose forest edges to bark beetle infestations. Eur J Forest Res 132: 453-465.

Kindlmann P, Křenová Z (2016) Biodiversity: Protect Czech park from development. Nature 531: 448.

Kindlmann P, Matějka K, Doležal P (2012) Lesy Šumavy, lýkožrout a ochrana přírody. Karolinum, Praha. In Czech.

Kučerová A, Rektoris L, Štechová T, Bastl M (2008) Disturbances on a wooded raised bog - How windthrow, bark beetle and fire affect vegetation and soil water quality? Folia Geobotanica 43: 49-67.

Matějka K, Starý J, Boháč J, Lepšová A, Špulák O (2016) Demonstration and research plots for monitoring of forest management in protected areas. https://www.infodatasys.cz /BiodivLes

Müller J, Bussler H, Gossner M, Gruppe A, Jarzabek-Müller A, Preis M, Rettelbach T (2007) Forest edges in the mixed-montane zone of the Bavarian Forest National Park - hot spots of biodiversity. Silva Gabreta 13: 121-148.

Nikolov Ch, Konôpka B, Kajba M, Galko J, Kunca A, Janský L (2014) Post-disaster Forest Management and Bark Beetle Outbreak in Tatra National Park, Slovakia. Mt Res Dev 34: 326-335.

Økland B, Netherer S, Marini L (2015) The Eurasian spruce bark beetle - role of climate. The Eurasian spruce bark beetle: The role of climate. In: Bjorkman C, Niemela P (eds) Climate Change and Insect Pests. CABI Climate Change Series 7, Wallingford UK, pp 202-219.

Pokorný J (2011) Co dokáže strom. In: Kleczek J (ed) Voda ve vesmíru, na zemi, v životě a v kultuře. Radioservis Praha, pp 429-431. In Czech.

Schwarz JD (2013) Clearing forest may transform local and global climate. Scientific American, March 4.

Šantrůčková H, Vrba J et al. (2010) Co vyprávějí šumavské smrčiny: průvodce lesními ekosystémy Šumavy. Správa Národního parku a Chráněné krajinné oblasti Šumava. In Czech.

Šíp M (2004) Remote sensing and its application in the public relations work of the national parks Bayerischer Wald and Šumava. Aktuality šumavského výzkumu II: 306-310.

Tesař M, Šír M, Zelenková E (2004) Vliv vegetace na vodní a teplotní režim tří povodí ve vrcholovém pásmu Šumavy. Aktuality šumavského výzkumu II: 84-88. In Czech.

Wermelinger B (2004) Ecology and management of the spruce bark beetle Ips typographus - a review of recent research. Forest Ecol Manag 202: 67-82.

Zahradník P (2004) Ochrana smrčin proti kůrovcům. Lesnická práce, Kostelec nad Černými lesy. In Czech. 